\title{
Quaternary molluscan faunas from the island of Tierra del Fuego after the Last Glacial Maximum*
}

\author{
SANDRA GORDILLO ${ }^{1,2}$, ANDREA MARIA JOSEFA CORONATO ${ }^{3}$ \\ and JORGE OSCAR RABASSA ${ }^{3}$ \\ ${ }^{1}$ Centro de Investigaciones Paleobiológicas (CIPAL), Universidad Nacional de Córdoba, Avda. Vélez Sárfield 299, 5000, \\ Córdoba, Argentina. E-mail: sgordillo@efn.uncor.edu \\ ${ }^{2}$ Consejo Nacional de Investigaciones Científicas (CONICET, AR). \\ ${ }^{3}$ Centro Austral de Investigaciones Científicas (CADIC, CONICET) C.C. 92, 9410, Ushuaia, Tierra del Fuego, Argentina.
}

\begin{abstract}
SUMMARY: Palaeontological studies on postglacial molluscan faunas from marine deposits located along the northern coast of the Beagle Channel (lat. 54 $55^{\prime}$ 'S, long. $68^{\circ} 34^{\prime}-67^{\circ} 11^{\prime} \mathrm{W}$ ) showed differences of various molluscan assemblages during a period of climatic stability after deglaciation. Oceanographic changes, different local environmental conditions and/or episodes of minor climatic fluctuations are pointed out as causes for the variations in faunal composition. Comparison with Quaternary molluscs from Antarctica showed that these palaeofaunas overlap slightly at the species level, but have a considerable number of genera $(23 \%)$ and families $(50 \%)$ in common. These affinities and relationships are better explained on the basis of more recent migrating taxa than by ancient connections when the two regions formed part of the Weddellian Province.
\end{abstract}

Keywords: mollusc assemblages, Tierra del Fuego, Beagle Channel, palaeoenvironments, Quaternary.

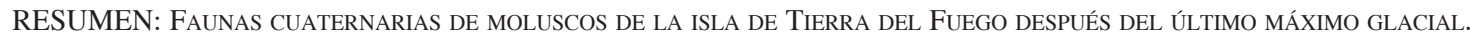
- Estudios paleontológicos en faunas de moluscos postglaciales hallados en depósitos marinos sobre la costa norte del Canal Beagle (lat. $54^{\circ} 55^{\prime} \mathrm{S}$; long. $68^{\circ} 34^{\prime}-67^{\circ} 11^{\prime} \mathrm{O}$ ) demostraron que las diferencias en varias asociaciones de moluscos ocurridas en un período de estabilidad climática después de la última deglaciación se deben a variaciones en la composición faunística que siguen a los cambios oceanográficos, a situaciones ambientales localmente diferentes y/o episodios con fluctuaciones climáticas menores. La comparación con moluscos cuaternarios de Antártica muestra que estas faunas tienen un ligero solapamiento a nivel especie, pero un considerable número de géneros $(23 \%)$ y familias en común (50\%). Estas afinidades y relaciones se explican mejor en base a migraciones recientes de taxones, que en base a antiguas conexiones cuando las dos regiones formaban parte de la Provincia Weddelliana.

Palabras clave: asociaciones de moluscos, Tierra del Fuego, Canal Beagle, paleoambientes, Cuaternario.

\section{INTRODUCTION}

Quaternary shallow molluscs are by far the most common taxa recovered and described in raised marine deposits along the eastern and southern coasts of the Isla Grande de Tierra del Fuego (Gordillo, 1992). These faunas are of considerable

*Received February 18, 2004. Accepted March 10, 2005. interest to life and earth scientists studying faunal change in these latitudes because Tierra del Fuego (Fig. 1) lies between the Atlantic and the Pacific oceans and had a common past with Antarctica as part of the Gondwana continent (Crame, 1993; 1996; 1999).

In addition, Quaternary climatic changes during the last 10,000 years (i.e. the Holocene) did not equally affect terrestrial and benthic marine ecosystems. 


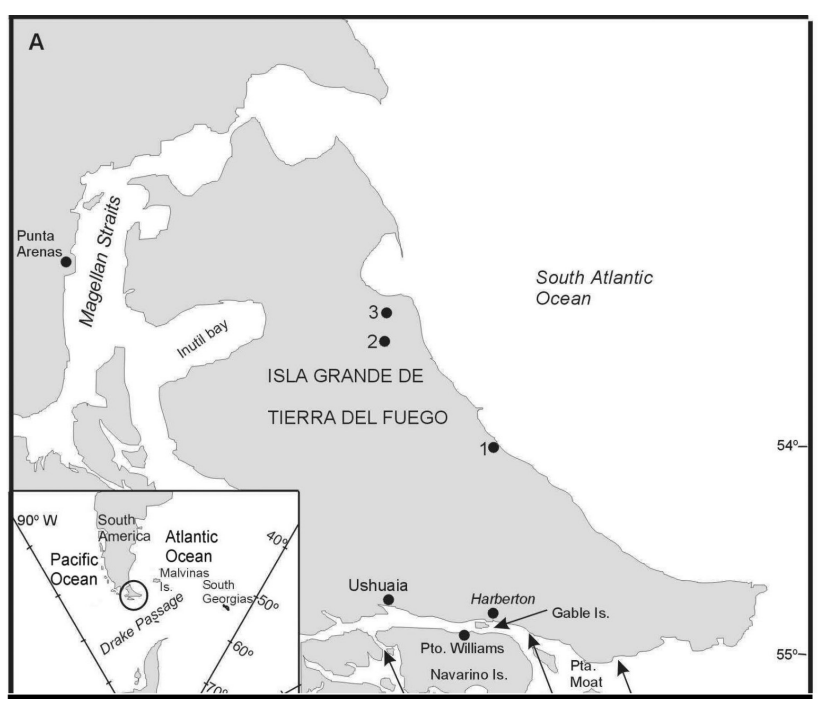

FIG. 1. - Map of Tierra del Fuego showing sites (A. labelled dots; B. black and white dots) with Quaternary molluscan faunas used for comparison with the Antarctic. Black dots (B) indicate sites considered to evaluate changes in faunal composition after deglaciation: Lago Roca, Río Ovando, Bahía Golondrina and Río Varela. References: 1. San Pablo; 2. Río Chico; 3. La Sara (unpublished data)

Expansion and recession of terrestrial vegetation from the Beagle Channel area reflect changes from warm and dry in the Early Holocene to cool and wet in the Middle to Late Holocene (Heusser, 1998). In opposition, marine molluscs from the same area reveal a period of climatic stability during the past 8 ka BP (Gordillo, 1999). Thus, episodes of minor climatic fluctuations that have slightly affected these associations composed of wide ecological amplitude taxa cannot be ruled out (Gordillo et al., 1992). These examples show that cross-disciplinary research provides frameworks for evaluating ecosystem responses to climate variations during Holocene times.

Taphonomic analysis to evaluate the fidelity of fossil assemblages, and whenever possible the reconstruction of palaeocommunities and their palaeotrophic structure, have been carried out previously (Gordillo, 1999). The available palaeoenvironmental information, including previous and new data, will be analysed together in this work. It deals with postglacial faunal changes and migration patterns that probably affected these faunas in the recent past.

Following a review of some different geological and physical factors capable of affecting faunal distributions in the region, a synthesis of the major events after the Last Glacial Maximum associated with the environmental evolution of an area located on the northern Beagle Channel coast will be given. Finally, a comparison with Quaternary molluscan faunas from Antarctica will be made.

\section{MATERIAL AND METHODS}

Palaeontological work in this paper is concentrated on four localities (Fig. 1B, black dots) located on the northern coast of the Beagle Channel: Lago

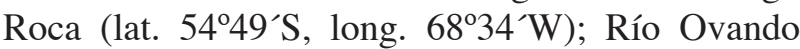

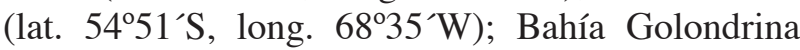
(lat. 54 $50^{\circ} \mathrm{S}$, long. $68^{\circ} 19^{\prime} \mathrm{W}$ ) and Río Varela (lat. $54^{\circ} 12^{\prime} \mathrm{S}$, long. $67^{\circ} 11^{\prime} \mathrm{W}$ ). These sites are considered as suitable for the preservation of small, thin shells.

The new records, especially small taxa and juvenile specimens, were collected in December 2002. In the field, small specimens were recovered from the marine deposits using a bulk sampler operated by hand. In the laboratory, the total volume of sediment was sieved on a $0.5 \mathrm{~mm}$ mesh size, and the material retained was sorted manually under a binocular microscope. Specimens were deposited in the Quaternary mollusc collection from Tierra del Fuego (TDF-Q) at the Centro de Investigaciones Paleobiológicas (CIPAL), Universidad Nacional de Córdoba (Córdoba, Argentina).

The systematics is based on previous identification carried out by Gordillo (1992), but recent taxonomic revisions on living mollusca by Linse (1999a), Ponder and Worsfold (1994) and Reid and Osorio (2000), among others, are also taken into account. The comparison with Quaternary mollusca from the Antarctic was made on the basis of all

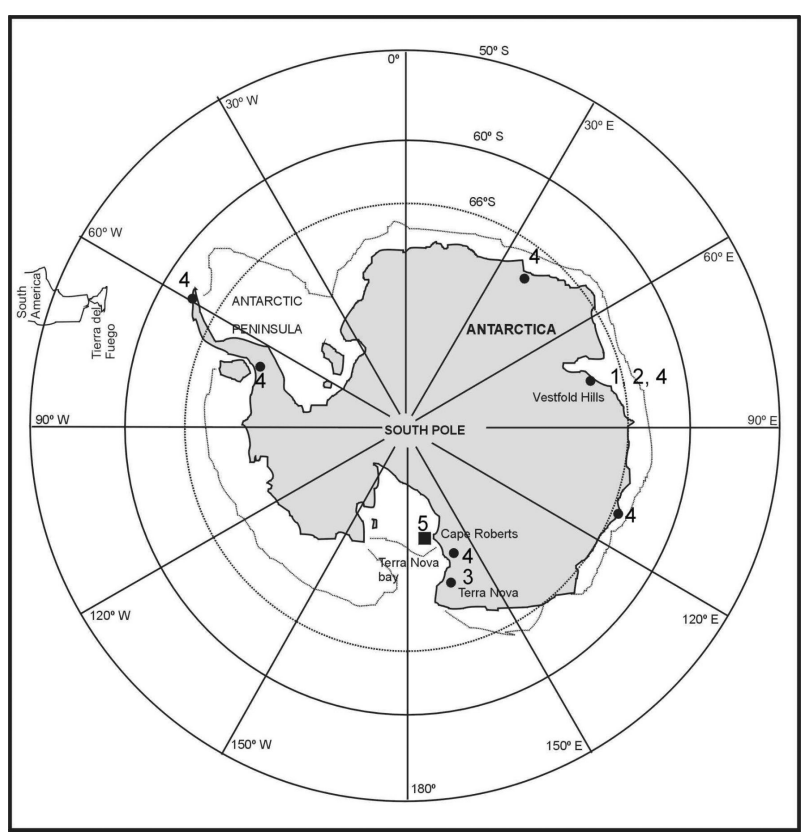

FIG. 2. - Map of Antarctica showing the location of sites with Quaternary Mollusca: raised beaches are pointed out with black dots and drillcores with black squares. References: 1. Zhang et al., 1983; 2. Pickard (1985); 3. Baroni and Orombelli (1991); 4. Berkman (1992); 5. Taviani et al. (1998). 
available fossil records from Tierra del Fuego (Fig. 1A, three numbered dots and Fig. 1B, black and white dots; Gordillo 1992, 1999; unpublished data). Records from different localities around Antarctica (Fig. 2)-including raised beaches and drillcore data-were taken from Baroni and Orombelli (1991), Clapperton and Sugden (1982), Orombelli et al. (1991), Pickard (1985), Pickard et al. (1983, 1986), Taviani et al. $(1998,2000)$ and Zhang et al. (1983). Information on mollusca from Quaternary deposits in the Buenos Aires province (Argentina; Aguirre, 1990), on the northern Atlantic Argentine coast, was used for a broader scale comparison.

\section{GEOLOGICAL AND PHYSICAL FACTORS AFFECTING FAUNAL DISTRIBUTIONS IN SOUTHERN SOUTH AMERICA}

\section{Plate tectonics, glaciations and Antarctic Con- vergence as barriers and/or dispersal routes}

Mesozoic/Earliest Cenozoic. It is known that in the geological past the Magellan region-as the southern part of South America-was linked to other parts of Gondwana, such as Antarctica, New Zealand and Australia, with a final phase of fragmentation occurring during the latest Mesozoic and earliest Cenozoic (Briggs, 1995). During the beginning of this phase these continents were separated by shallow seas. This region extended from West Antarctica into both southern South America and eastern Australia. Because of the overall uniformity of the faunas, it is considered to represent a single broad biogeographic province, designated by Zinsmeister (1979) as the Weddellian Province. It appears that this high latitude region acted as a centre of origin and dispersal for a broad spectrum of taxa, including molluscs (Zinsmeister and Feldmann, 1984; Crame, 1992).

Late Cenozoic. In the marine realm, it seems that climatic deterioration during Plio-Pleistocene glaciations produced environmental changes that normally resulted in regional or local extinctions followed by a repopulation by migrants from other areas (hypothesis of "ecological opportunity"; Vermeij, 1991). In the Southern Ocean, Pickard et al. (1983) suspected that during Quaternary glaciations the fauna either survived and dispersed from ice-free refugia or immigrated from nearby South America or Antarctica. Crame (1997) too considered that during most glacial advances in the Antarctic region, the marine fauna would have had to retreat into some form of refugia; an unglaciated part of the shelf, or the deeper waters of the outermost shelf (or top of the slope), or one of the Subantarctic islands. This strategy could explain the considerable degree of evolutionary stability within Antarctic molluscan faunas over the last $40 \mathrm{Ma}$.

Some similarities between faunas from different regions in the southern seas could also be explained by considering the West Wind Drift circulation in more recent times. It is possible that the opening of the Drake Passage (25-22 Ma.) and the completion of circum-Antarctic deep water circulation may have promoted various forms of both vicariance and dispersal (Crame, 1999). For example, Beu et al. (1999) recognised three phases of dispersal between South America and New Zealand via the West Wind Drift; the last one, the Pleistocene phase, involved at least several mollusc taxa (Mytilus, Protothaca and Tawera, among others). Moyano (1999) pointed out that a real path for migrating bryozoans is the chain of archipelagos stretching between the southernmost tip of South America and the northernmost tip of the Antarctic Peninsula. In this regard, it is important to note that the Antarctic Convergence, as the main physical barrier between Antarctica and the Magellan region, appears to be crossed by several taxa (Antezana, 1999b; Moyano, 1999).

It has not yet been determined whether Antarctic taxa inhabiting Tierra del Fuego migrated via the Scotia Ridge and/or inversely Antarctic derived taxa migrated to the Fuegian region.

\section{Glaciations and faunal exclusion in the Beagle Channel}

The Beagle Channel is a $200 \mathrm{~km}$ long drowned glacial valley formerly occupied by the "Beagle Glacier", a large outlet glacier which flowed from the Cordillera Darwin (lat. 55 $\mathrm{S}$; long $69^{\circ} \mathrm{W}$; Fig. 1). This valley was repeatedly glaciated, at least in two major episodes, and the ice occupied the entire channel basin as far east as Bahía Sloggett during the "Lennox Glaciation" (Oxygen Isotopic Stage -OIS- 6) and Punta Moat during the "Moat Glaciation" (OIS 2, 24 cal.; Rabassa et al., 1990; 1992; 1996; 2000).

It is suspected that during glaciations the ice excluded much of the benthic marine fauna inhabiting the marine environment, as was the case in the Arctic region with the Laurentide ice during the last Wisconsinan glaciation (Lubinsky, 1980). In the study region, a few poorly preserved specimens 
included in compact lodgement tills in Bahía Golondrina (Rabassa et al., 1986) and Isla Gable (Gordillo, 1990) respectively were probably deposited either when a glacier advanced over pre-existing marine deposits, perhaps of Mid-Wisconsian or Sangamonan age, or when the advancing glacier was in contact with the sea level. Anyway, these records indicate that the Beagle Channel had been occupied by sea water at least once before the late Wisconsinan maximum. During glaciations, as indicated previously by Crame (1996), species were able to persist by moving into deeper water or moving into warmer regions, or perhaps survived in unglaciated pockets on continental shelves.

\section{Other physical factors affecting taxa distribution in the Beagle Channel: sills, tides, currents and depth.}

A water mass characterisation of the Beagle Channel system has been proposed by Antezana (1999a). Despite major connections to the Pacific Ocean at the mouth of the Beagle Channel, the presence of shallow sills is likely to constrain water exchange to the upper $30-40 \mathrm{~m}$. In particular, the shallow depth of the eastern end of the Beagle Channel apparently restricts the inflow of subsurface ocean water. As water exchange with the Pacific Ocean is limited and it apparently takes place through narrow and shallow openings, most of the water filling the Fuegian basin must be semi-isolat- ed or trapped seasonally. The currents and tides and the depth are probably important factors determining basin to basin linkages.

The Beagle Channel has been described as an estuary by Isla et al. (1999), since thermal stratification and water mixing at $12 \mathrm{~m}$ depth was observed near the western Isla Gable cliffs (Fig. 1). It was assumed that this island acts as a sill in the estuarine dynamics generating the joining of tidal waves and the consequent sediment accumulation, and forms an obstruction to the wind-streams which promotes high wave erosion on the western side of the island. Sediment capture and decantation occur in the western waters of Isla Gable, whereas to the east greater depth allows the accumulation of weathered bedrock clays and silts, and sand and gravel in the rare shallow waters (Isla et al., 1999).

Physical characteristics that are locally different, as mentioned above, probably influence the species composition of plankton between nearby inlets and may cause complex patterns of retention, dispersal and exchange of plankton species between fjords (Antezana, 1999b).

Links to the Antarctic and other Subantarctic regions can also be explained by examining bathymetry and hydrography. For example, Antezana (1999b) has noted that the Polar Front-while meandering across the Pacific Ocean near South America-may form cold rings which transport endemic Antarctic plankton communities into warmer regions as they fade away in the course of

TABLE 1. - Physical and palaeontological characterisation of four sites on the Beagle Channel.

\begin{tabular}{|c|c|c|c|c|}
\hline Characterisation & Lago Roca & Río Varela & Río Ovando & Bahía Golondrina \\
\hline Assemblage type & $\begin{array}{l}\text { Parauthochthonous } \\
\text { assemblage; } \\
\text { Epifaunal community }\end{array}$ & $\begin{array}{l}\text { Allochthonous } \\
\text { assemblage }\end{array}$ & $\begin{array}{l}\text { Authochthonous } \\
\text { assemblage; } \\
\text { Semi-infaunal community }\end{array}$ & $\begin{array}{l}\text { Authochthonous } \\
\text { assemblage; } \\
\text { Infaunal community }\end{array}$ \\
\hline Elevation (a.s.1.) & $3.0 \mathrm{~m}$ & $3.0 \mathrm{~m}$ & $2.5 \mathrm{~m}$ & $2.0 \mathrm{~m}$ \\
\hline $\begin{array}{l}\text { Uncorrected radiocarbon } \\
\text { age and } \mathrm{C}^{14} \text { laboratory } \\
\text { sample code }\end{array}$ & $\begin{array}{l}7518+/-58 \text { yr BP } \\
\text { (NZ-7730; Gordillo } \\
\text { et al., 1993) }\end{array}$ & $\begin{array}{l}6240+/-70 \text { yr BP } \\
\text { (Pta } 7581 ; \text { Coronato } \\
\text { et al., 1999) }\end{array}$ & $\begin{array}{l}4160+/-45 \text { yr BP } \\
\text { (Pta } 7573 ; \text { Coronato } \\
\text { et al. } 1999)\end{array}$ & $\begin{array}{l}\text { Not dated; } \\
1400+/-300 \text { yr BP } \\
\text { (+2.7 m a.s.1.; Urien, 1968) }\end{array}$ \\
\hline $\begin{array}{l}\text { Distance from the Beagle } \\
\text { Channel }\end{array}$ & $2500 \mathrm{~m}$ & $500 \mathrm{~m}$ & $1000 \mathrm{~m}$ & $30 \mathrm{~m}$ \\
\hline Regional climate conditions & Deglaciation & $\begin{array}{l}\text { Maximum Neoglacial } \\
(\mathrm{I}-\mathrm{II})\end{array}$ & Warmer conditions & $\begin{array}{l}\text { Neoglacial events } \\
\text { (III - VII) }\end{array}$ \\
\hline Range of time & $10-6.5 \mathrm{ka}$ & $6.5-4.5 \mathrm{ka}$ & $4.5-4.0 \mathrm{ka}$ & $3.5 \mathrm{ka}-$ present \\
\hline
\end{tabular}

$\mathrm{Ka}=1000$ years 
several months. After passing the shallow sills at the mouth of inland passages, these organisms are probably trapped within the system, and become expatriates or vagrants, as must be the case for Subantarctic and Atlantic species in the Fuegian fjords.

\section{ENVIRONMENTAL EVOLUTION AFTER THE LAST GLACIAL MAXIMUM}

Based on multiple kinds of data such as geomorphological, stratigraphical and palaeontological studies, neontology, radiocarbon dates and isotopic analyses, the environmental evolution of the northern coast of the Beagle Channel microbasin can be interpreted.

The physical and palaeontological characterisation of the four sites is summarised in Table 1.

The assemblages are mostly composed of small taxa and juvenile specimens of gastropods and bivalves (Table 2). Each taxon is presently extant within the Beagle Channel (Linse, 1999a) and most of them are eurybathic, occurring in shallow and deeper waters. Other preserved groups include chitons, brachiopods, cirripedes, ostracods, foraminifers, echinoid remains and small fish vertebrae.

Previous analysis of these units (Gordillo, 1992; Gordillo et al., 1993; Gordillo, 1999), which considered post mortem mechanical processes (i.e. disarticulation, fragmentation, orientation, abrasion, bioerosion, overgrowth) affecting fossil remains, and their palaeontological attributes (i.e. taxa composition, abundance, size frequency, mode of life), showed that-despite the bias in preservation due to taphonomic processes - these assemblages retain useful information pertaining to life habit and habitats of the marine benthos from which they are derived.

The chronology and deglaciation history of this area has been summarised in previous works (Gordillo et al, 1993, Grill et al., 2002, Heusser, 1989a,b, Heusser and Rabassa, 1987; Rabassa et al. 1986, 1990, 1996, 2000). The radiocarbon dates used in this work are conventional ${ }^{14} \mathrm{C}$ age; they are uncorrected and not calibrated.

Thus, following the major events during postglacial times different phases can be distinguished:

\section{Phase 1: Deglaciation after the Last Glacial Maximum}

Evidence suggests that the Last Glacial Maximum in the Beagle Channel area and in the sur- rounding mountains took place $c a .20$ ka BP (Rabassa et al., 1990). By 12 ka BP the ice had probably disappeared from the southern coast at Puerto Williams (lat. 54 $56^{\circ} \mathrm{S}$, long $67^{\circ} 38^{\prime} \mathrm{W}$; Heusser, 1989a) and from the northern coast at Ushuaia (lat. $54^{\circ} 47^{\prime}$ S, long 68 $20^{\prime} \mathrm{W}$; Heusser, 1998). Large volumes of meltwater were discharged into the Beagle valley not only from the main receding glacier, but also from the meltwater streams coming from the valley glaciers located along both coasts.

No fossil marine benthic records were found for this period. This lack is probably related to the presence of unstable substrates not suitable for this kind of fauna, since the incoming freshwater and the consequent influx of continental organic matter must have restricted marine circulation and nutrient regeneration, creating food-limited benthic habitats, especially for suspension feeders.

\section{Phase 2: Early Holocene conditions}

Since $10 \mathrm{ka}$ BP meltwater influx into the Beagle Channel has decreased sharply. Mean sea temperature has been estimated as $3-6^{\circ} \mathrm{C}$ lower than at present (Heusser, 1989a, b). The maximum transgressive episode occurred between 9 and $7 \mathrm{ka} \mathrm{BP}$ (Isla, 1989). Around $8 \mathrm{ka}$ BP the present Beagle Channel, as one of the inland passages in the complex network of channels, inlets and islands of the Fuegian Archipelago, was occupied by marine waters that flooded progressively via constricted waterways connected to the open ocean. This episode might correlate with the oldest sea level identified at Bahía Lapataia (8240 +/- 60 yr BP; Rabassa et al., 1986) and with the highest sea level at Lago Roca (7518 +/- 58 yr BP; Gordillo et al., 1993).

This area was a valley-glacier system during the Last Glacial Maximum, but after the deglaciation it was flooded by sea waters from the Beagle Channel and converted into a complex marine inlet. Around $8 \mathrm{ka}$. BP, the Lago Roca-Lapataia area was a low energy, freshwater estuarine environment, but around $7.5 \mathrm{ka} \mathrm{BP}$, during the Holocene marine transgression, the whole area turned into a fjord (Gordillo et al., 1993), and Lago Roca and Río Ovando (located in its vicinity) became a shallow marine environment.

Fossil record. Although not described here, it is mentioned that earlier migrants after deglaciation (around $8 \mathrm{ka} \mathrm{BP}$ ) are represented by mytilids and cirripeds, collected from the oldest postglacial raised beach at Bahía Lapataia (Gordillo, 1992). 
TABLE 2. - Preliminary list of molluscs recorded from the four sites.

\begin{tabular}{|c|c|c|c|c|}
\hline & Lago Roca & Río Varela & Río Ovando & Bahía Golondrina \\
\hline \multicolumn{5}{|l|}{ GASTROPODA } \\
\hline $\begin{array}{l}\text { Patellidae } \\
\text { "Nacella" spp. }\end{array}$ & $X$ & & $\mathrm{X}$ & \\
\hline Fissurellidae & & & & \\
\hline $\begin{array}{l}\text { Fissurella spp. } \\
\text { Scissurellidae }\end{array}$ & & $\mathrm{X}$ & $\mathrm{X}$ & \\
\hline $\begin{array}{l}\text { Scissurella timora? Melvill and Standen, } 1912 \\
\text { Scissuae }\end{array}$ & & & $\mathrm{X}$ & \\
\hline Trochidae & & & & \\
\hline $\begin{array}{l}\text { Calliostoma cf. nudum (Philippi, 1845) } \\
\text { Margarella violacea (King and Broderip, 1831) }\end{array}$ & \multicolumn{2}{|c|}{$\begin{array}{l}\text { Margarella violacea (King and Broderip, 1831) } \\
\text { Orbitestellidae }\end{array}$} & $\mathrm{X}$ & $\mathbf{Y}$ \\
\hline 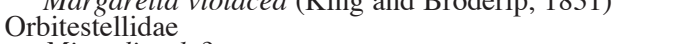 & $X$ & $X$ & $X$ & $X$ \\
\hline Microdiscula? sp. & & & $\mathrm{X}$ & \\
\hline Cyclotrematidae & & & & \\
\hline Cirsonella sp. & & & $\mathrm{X}$ & \\
\hline $\begin{array}{l}\text { Cerithiopsidae } \\
\text { Eumetula pulla (Philippi, 1845) }\end{array}$ & $\mathrm{X}$ & $\mathrm{X}$ & $\mathrm{X}$ & \\
\hline Eumetula michaelseni (Strebel, 1906) & $\mathrm{X}$ & & & \\
\hline \multicolumn{5}{|l|}{ Turritelidae } \\
\hline $\begin{array}{l}\text { Mathilda aff. malvinarum (Melvil and Standen, 1907) } \\
\text { Colpospirella algida (Melvil and Standen, 1912) }\end{array}$ & $\mathrm{X}$ & $X$ & & \\
\hline \multicolumn{5}{|l|}{ Omalogyridae } \\
\hline $\begin{array}{c}\text { Omalogyra antarctica Egorova, } 1991 \\
\text { Littorinidae }\end{array}$ & & & $X$ & \\
\hline \multicolumn{5}{|l|}{$\begin{array}{l}\text { Littorinidae } \\
\text { Laevilitorina caliginosa Gould, } 1848 \\
\text { Eatoniellidae }\end{array}$} \\
\hline $\begin{array}{l}\text { Eatoniellidae } \\
\quad \text { Eatoniella spp. }\end{array}$ & & & & \\
\hline $\begin{array}{l}\text { Eatoniella spp. } \\
\text { Rissoidae }\end{array}$ & $\mathrm{X}$ & & $\mathrm{X}$ & $\mathrm{X}$ \\
\hline $\begin{array}{l}\text { Rissoidae } \\
\text { Onoba spp. }\end{array}$ & $\mathrm{X}$ & $\mathrm{X}$ & $\mathrm{X}$ & $\mathrm{X}$ \\
\hline \multicolumn{5}{|l|}{ Calyptraeidae } \\
\hline Trochita pileolus (Orbigny, 1845) & $\mathrm{X}$ & & $\mathrm{X}$ & \\
\hline Trochita pileus (Born, 1778) & & $\mathrm{X}$ & & $\mathrm{X}$ \\
\hline $\begin{array}{l}\text { Capulidae } \\
\text { Capulus? sp. }\end{array}$ & & & & $X$ \\
\hline \multicolumn{5}{|l|}{ Buccinulidae } \\
\hline Metheutria martensi (Strebel, 1905) & $\mathrm{X}$ & $\mathrm{X}$ & $\mathrm{X}$ & \\
\hline Pareuthria spp. & $\mathrm{X}$ & $\mathrm{X}$ & $\mathrm{X}$ & \\
\hline Savatieria frigida Rochebrune and Mabille, 1885 & $\mathrm{X}$ & & $\mathrm{X}$ & \\
\hline \multicolumn{5}{|l|}{ Muricidae } \\
\hline Xymenopsis muriciformis (King and Broderip, 1832) & $\mathrm{X}$ & $\mathrm{X}$ & & \\
\hline $\begin{array}{l}\text { Xymenopsis buccinea Lamarck, } 1816 \\
\text { Trophon geversianus (Pallas, 1769) }\end{array}$ & & $\mathrm{X}$ & $X$ & \\
\hline Fuegotrophon pallidus Broderip and Sowerby, 1833 & & $\hat{X}$ & $\mathrm{X}$ & \\
\hline $\begin{array}{l}\text { Pyramidellidae } \\
\text { Turbonilla smithi (Strebel. 1905) }\end{array}$ & & & $X$ & \\
\hline $\begin{array}{l}\text { Turbonilla smithi (Strebel, 1905) } \\
\text { Sum of families }\end{array}$ & 9 & 9 & $\begin{array}{l}X \\
15\end{array}$ & 6 \\
\hline Sum of taxa & 12 & 12 & 19 & 6 \\
\hline \multicolumn{5}{|l|}{ BIVALVIA } \\
\hline \multicolumn{5}{|l|}{ Nuculidae } \\
\hline Linnucula pisum (Sowerby, 1832) & $\mathrm{X}$ & & $\mathrm{X}$ & \\
\hline $\begin{array}{l}\text { Nucula spp. } \\
\text { Malletidae }\end{array}$ & & $\mathrm{X}$ & $\mathrm{X}$ & $\mathrm{X}$ \\
\hline $\begin{array}{l}\text { Malletidae } \\
\text { Tyndariopsis sulcata (Couthouy, 1852) }\end{array}$ & $\mathrm{X}$ & & $\mathrm{X}$ & \\
\hline \multicolumn{5}{|l|}{$\begin{array}{l}\text { Iyndarlopsis sulcata (Couthouy, 1852) } \\
\text { Philobryidae }\end{array}$} \\
\hline $\begin{array}{l}\text { Philobrya sublaevis? Pelseneer, } 1903 \\
\text { Lissarca miliaris (Philippi, 1845) }\end{array}$ & $X$ & & $\underset{\mathrm{X}}{\mathrm{X}}$ & \\
\hline \multicolumn{5}{|l|}{$\begin{array}{l}\text { Llssarca milıarls (Philıpp1, 1845) } \\
\text { Mytilidae }\end{array}$} \\
\hline Aulacomya atra atra (Molina, 1782) & & & $\mathrm{X}$ & \\
\hline Mytilus sp. & & & $\mathrm{X}$ & \\
\hline Pectinidae & & & & \\
\hline Zygochlamys patagonica (King and Broderip, 1832) & $\mathrm{X}$ & & & \\
\hline $\begin{array}{l}\text { Limidae } \\
\text { Limatula pygmaea (Philippi, 1845) }\end{array}$ & & & $\mathrm{X}$ & \\
\hline Leptonidae & & & & \\
\hline Neolepton sp. & $\mathrm{X}$ & $\mathrm{X}$ & $\mathrm{X}$ & $\mathrm{X}$ \\
\hline $\begin{array}{l}\text { Erycinidae } \\
\text { Lasaea spp. }\end{array}$ & $\mathrm{X}$ & $\mathrm{X}$ & $X$ & \\
\hline Montacutidae & & & & \\
\hline $\begin{array}{l}\text { Mysella aff. miniuscula (Martens and Pfeffer, 1908) } \\
\text { Cyamiidae. }\end{array}$ & $\mathrm{X}$ & $\mathrm{X}$ & & \\
\hline $\begin{array}{l}\text { Cyamiidae } \\
\text { Cyamium spp. }\end{array}$ & $X$ & $X$ & $\mathrm{X}$ & $\mathrm{X}$ \\
\hline $\begin{array}{l}\text { Cyamium spp. } \\
\text { Carditidae }\end{array}$ & $X$ & $X$ & $X$ & $X$ \\
\hline Carditella naviformis (Reeve, 1843) & & & $\mathrm{X}$ & \\
\hline Carditopsis flabellum (Reeve, 1843) & & & $\mathrm{X}$ & \\
\hline Cyclocardia compressa (Reeve, 1843) & & & $\mathrm{X}$ & \\
\hline Solenidae & & & & \\
\hline Ensis macha (Molina, 1782) & & & & $\mathrm{X}$ \\
\hline Veneridae & & & & \\
\hline Protothaca antiqua (King, 1831) & & $\mathrm{X}$ & & $\mathrm{X}$ \\
\hline Retrotapes exalbidus (Dillwyn, 1817) & & $\mathrm{X}$ & $X$ & \\
\hline Tawera gayi (Hupé, 1854) & & & $\mathrm{X}$ & \\
\hline Hiatellidae & & & & \\
\hline Hiatella solida (Sowerby, 1834) & $X$ & $X$ & $\mathrm{X}$ & $X$ \\
\hline Sum of families & 9 & 7 & 11 & 7 \\
\hline Sum of taxa & 9 & 8 & 17 & 7 \\
\hline
\end{tabular}

342 S. GORDILLO et al. 
These taxa are epibenthic and tolerate estuarine conditions. The other bed, the Lago Roca deposit, was previously considered in Gordillo et al. (1993) and Gordillo (1999). The presence and dominance of suspension feeders in the epifaunal Zygochlamys patagonica palaeocommunity (Gordillo, 1999) showed that marine conditions were fully established around 7.5 ka BP. The predominance of epifauna is most probably associated with the prevalence of firmground substrates more suitable to these groups.

\section{Phase 3: Middle Holocene climatic deterioration}

Several palaeoclimatic records have demonstrated that cold climatic conditions occurred $c a .6 \mathrm{ka} \mathrm{BP}$ along the Beagle Channel. At the Río Varela site marine waters flooded the present mouth area at $c a$. 6.2 ka BP (6240 +/- 70 yr BP; Coronato et al., 1999), developing a shallow, low-energy, nearshore environment, strongly fluvially influenced and seasonally ice-covered (Grill et al., 2002). Apparently, a phase of climatic deterioration in the region took place between 6.5 and 5 ka BP (Obelic et al., 1998; Grill et al., 2002), but its origin remains unclear.

Fossil record. The sequence at Río Varela site is a succession of marine sediments and organic horizons which underlie fluvial sediments (Grill et al., 2002). From base to top, several stratigraphic units were identified. The basal unit consists of massive greyish clays containing shells. This assemblage is composed of a mixing of epifauna and infauna. Taphonomic analysis indicates that it corresponds to an allochthonous, transported assemblage. However, the presence of venerids and other infaunal taxa showed that around $6 \mathrm{ka}$ BP in the Beagle Channel physical conditions were suitable to the development of organisms associated with soft substrata. Considering that both kinds of organisms (epifauna and infauna) are able to live at present in the Beagle Channel, the absence of Pectinidae may be more related to taphonomic biases or the distinctly patchy distribution of epifaunal communities in the Magellan region (Linse, 1999b) than to a regional or local absence due to a retraction of this group associated with minor climatic changes.

\section{Phase 4: Middle Holocene climatic amelioration}

Palynological records taken from the surrounding peat-bogs in the area indicate cool conditions with significant forest expansion between 4 and 2 ka. BP (Heusser, 1998). However, this cooler and more humid period was probably preceded by a short period of warmer conditions between 4.5 and $4 \mathrm{ka} \mathrm{BP}$, as pointed out by Obelic et al. (1998) in the marine realm.

Palaeotemperatures presented by these authors, calculated from oxygen isotopic composition in shells from archaeological sites along the Beagle Channel, indicate higher temperature values for the period 4.5-4 ka BP. Our own data support the view that around $4.5 \mathrm{ka} \mathrm{BP}$ the marine conditions persisted well-developed within the Lago Roca-Lapataia area, forming a true marine archipelago (Rabassa et al., 1986; Gordillo et al., 1993). Then, the sea level continued its relative regression until it reached the present conditions as a freshwater archipelago.

Fossil record. A well-developed raised marine terrace at the head of the Río Ovando was described by Rabassa et al. (1986). This unit consists of coarse sands and pebbles of varied lithology and marine shells, lying on greenish clays with mytilid fragments. Extensive beds of Veneridae (Tawera gayi, Protothaca antiqua, Retrotapes exalbidus) and other molluscs in growth position (Hiatella solida) characterise the area. Considering palaeotemperatures and the diversification of this fauna (e.g. the appearance of the Carditidae in these beds, which is the most notable addition), it appears that the Río Ovando associations (4.4-4.1 ka BP) correspond to warmer waters. Finally, another characteristic of these assemblages is the incidence of drilling (approximately 25\% of the shells are bored). Thus, predation by boring gastropods is apparently more effective in lower-warmer latitudes (Vermeij, 1978; 1995).

All this information is interpreted here in the way that during this phase a major expansion of the fauna with further diversification of taxa took place, indicating an evolution towards modern conditions.

\section{Phase 5: Late Holocene neoglacial events}

Neoglaciation of terrestrial ecosystems is represented in this phase by several ice readvances or glacial episodes which took place in the glacial cirques and summits of the surrounding mountains above $900 \mathrm{~m}$ (Rabassa et al., 1992; Planas et al., 2002). No absolute dates are available for the Fuegian Andes, although many correlations with neoglacial episodes occurring after $3.5 \mathrm{ka}$ BP in Darwin Cordillera, Subantarctic Islands and Antarctica have been suggested (Clapperton and Sudgen, 
1988; Kuylenstierna et al., 1996; Strelin et al., 2002). In the marine realm, measurements of palaeotemperatures from the Beagle Channel show a fall in values at about 3.5-3 ka BP (Obelic et al., 1998).

Fossil record. Deposits from this area were previously studied by Auer (1959), Urien (1968) and Gordillo (1992, 1999). This section (> $1 \mathrm{~m})$, composed of fine, greyish sandy sediments was considered in Gordillo (1999). The lack of sedimentary structures and macrofossils in life position (Ensis macha, Protothaca antiqua) was interpreted as being due to rapid accumulation processes, probably caused by regional storms in the region.

No radiocarbon dating has been performed for this level, but considering its proximity and their similar elevation, it could be correlated with the lowest level of $1400+/-300 \mathrm{yr}$ BP described by Urien (1968) at $5 \mathrm{~m}$ above sea level.

An impoverishment in this association with respect to the others is recognised. Buccinulidae, Muricidae, Cerithiopsidae and Malletidae are all missing. Although not rejected, these differences do not necessarily reflect advances or retractions of taxa associated with minor climatic fluctuations. It is plausible that this absence is related to taphonomic biases (noise) and/or to the nature of the substratum that creates patchy distributions of benthic communities along the Beagle Channel.

\section{COMPARISON WITH QUATERNARY MOLLUSCA FROM ANTARCTICA}

Age and altitude. Our data showed that the oldest postglacial raised beaches occurring in Tierra del Fuego (Bahía Lapataia: 8240 +/- 60 yr BP; Rabassa et al., 1986; 7770+/- 130 yr B.P., Borromei and Quattrochio, 2001) are comparable in age (ca. 8-7 ka $\mathrm{BP})$ with those in West Antarctica (Victoria Land: $7505+/-230$ yr BP; Orombelli et al., 1991) and East
Antarctica (Vestfold Hills: 7590+/-80 yr BP; Pickard, 1985). However, Holocene uplifted deposits in Antarctica containing shells in situ reach altitudes that usually exceed $10 \mathrm{~m}$ (Orombelli et al., 1991; Ingólfsson et al., 2003), while their equivalents from Tierra del Fuego do not exceed $10 \mathrm{~m}$ above the present sea level.

Distribution and dominance. Berkman (1992) showed that Holocene marine molluscs from Antarctica have a circumpolar distribution, and they represent the most consistent circumpolar fossil record. This consistency and dominance is also evident from our data in Tierra del Fuego (Gordillo, 1992).

Climatic conditions. In taxa composition and molluscan assemblages the postglacial molluscs from the Beagle Channel correspond to the fauna living in the region today. Thus, climatic conditions remained stable enough to allow the survival of the same marine faunistic associations, which have a wide ecological range equivalent to taxa living today (Gordillo, 1999). This wide ecological range is also evidenced in the Antarctic Holocene (Pickard, 1985). Living Antarctic forms also have very extensive depth ranges (Dell, 1990), and it is not possible to set any meaningful depth limit for analytical purposes; thus, a simple division into shallow and deep water faunas is impractical in the Antarctic region (Crame, 2000). With local variations, a climatic optimum starting after $4.2 \mathrm{ka} \mathrm{BP}$ is recognised for different regions in the Antarctic (Ingólfsson et al., 1998; 2003). Warmer conditions between 4.5-4 ka BP (phase 4 in this work) are also evidenced in the Beagle Channel waters from isotopic analysis by Obelic et al. (1998).

Taxonomic composition. Zoogeographic studies on living molluscs from the Magellan region have shown that this region shares taxa with the Antarctic. Brandt et al. (1999) obtained the highest percentage of shared species within bivalves (29\%), and Linse (2002) found that the regions around the Antarctic continent share species with percentages

TABLE 3. - Number of shelled fossil and living taxa from Tierra del Fuego and the Antarctic.

\begin{tabular}{|c|c|c|c|c|c|c|}
\hline Region & No. of species & $\begin{array}{l}\text { Gastropoda } \\
\text { No. of genera }\end{array}$ & No. of families & No. of species & $\begin{array}{c}\text { Bivalvia } \\
\text { No. of genera }\end{array}$ & No. of families \\
\hline \multicolumn{7}{|l|}{ Fossil taxa } \\
\hline Tierra del Fuego & 47 & 33 & 23 & 32 & 31 & 19 \\
\hline Antarctic & 33 & 24 & 19 & 19 & 16 & 13 \\
\hline \multicolumn{7}{|l|}{ Living taxa (1) } \\
\hline Tierra del Fuego & 195 & 87 & 31 & 131 & 75 & 36 \\
\hline Antarctic & 207 & 90 & 37 & 68 & 32 & 21 \\
\hline
\end{tabular}

(1) Source of data on living mollusca: Tierra del Fuego (Linse, 1999a; Nudibranchia excluded). Antarctic (Dell, 1990). 
TABLE 4. - Taxonomic diversity.

\begin{tabular}{|c|c|c|c|c|c|c|}
\hline Region & DSG & $\begin{array}{c}\text { Gastropoda } \\
\text { DSF }\end{array}$ & DGF & DSG & $\begin{array}{c}\text { Bivalvia } \\
\text { DSF }\end{array}$ & DGF \\
\hline Tierra del Fuego & 0.979 & 0.950 & 0.963 & 0.997 & 0.954 & 0.952 \\
\hline Antarctic & 0.976 & 0.905 & 0.962 & 0.983 & 0.966 & 0.967 \\
\hline Buenos Aires & 0.984 & 0.939 & 0.983 & 0.912 & 0.972 & 0.981 \\
\hline
\end{tabular}

DSG: Species/genus diversity; DSF: Species/family diversity, DGF: Genus/family diversity.

TABLE 5. - Percentage of species, genera and families shared with the Antarctic and northern Argentina based on the Quaternary fossil record.

\begin{tabular}{lcccccc}
\hline $\begin{array}{l}\text { Region compared with } \\
\text { the Magellan region }\end{array}$ & Species & $\begin{array}{c}\text { Gastropoda } \\
\text { Genera }\end{array}$ & Families & Species & $\begin{array}{c}\text { Bivalvia } \\
\text { Genera }\end{array}$ & Families \\
\hline $\begin{array}{l}\text { Antarctic } \\
\text { Buenos Aires }\end{array}$ & $\begin{array}{l}3(\mathrm{n}=2) \\
4(\mathrm{n}=3)\end{array}$ & $\begin{array}{c}23(\mathrm{n}=11) \\
12(\mathrm{n}=6)\end{array}$ & $\begin{array}{c}50(\mathrm{n}=14) \\
31(\mathrm{n}=10)\end{array}$ & $\begin{array}{c}6(\mathrm{n}=3) \\
0\end{array}$ & $\begin{array}{c}23(\mathrm{n}=9) \\
6(\mathrm{n}=3)\end{array}$ & $\begin{array}{c}52(\mathrm{n}=11) \\
20(\mathrm{n}=6)\end{array}$ \\
\hline
\end{tabular}

of between 9.2 and $0.9 \%$, with decreased values towards the Scotia Arc islands.

In this work the taxonomic composition of Magellan molluscs focuses on shelled gastropods and bivalves from Tierra del Fuego. Tables 3 and 4 show taxonomic distribution and taxonomic diversity indices for fossil and living taxa respectively. Furthermore, shared taxa with the Antarctic and a portion of the northern Argentine coast (in the Buenos Aires province) are compared (Table 5). At species level there are no strong similarities, with values of less than $10 \%$ of species in common. When one considers the degree of overlap between Buenos Aires and Tierra del Fuego, there are still differences at genus and family levels, with overlaps of 6-12 and 20-30\%, respectively, but the Antarctic and Tierra del Fuego overlap to a higher degree, with $23 \%$ of genera and $50 \%$ of families in common.

Figure 3 compares the taxonomic distribution of Quaternary gastropods and bivalves from Tierra del Fuego with their equivalents from the Antarctic.

The bivalve families Veneridae, Mactridae and Mytilidae, which are well-represented in Tierra del Fuego, are absent in the Quaternary of the Antarctic. However, they were prominent in Palaeogene strata of this region (La Meseta Formation; Zinsmeister, 1984), and thereafter they diminished and disappeared. The costate pectinids (the Chlamys group) also appear to have become extinct in the Antarctic before the initiation of the Quaternary. These changes in faunal composition are perhaps not always associated with physiological limitations of these taxa under climatic deterioration or cooling, but could rather be linked to substrate changes (e.g. physical destruction of fine-grained substrates; Crame, 1996) associated with glaciations.

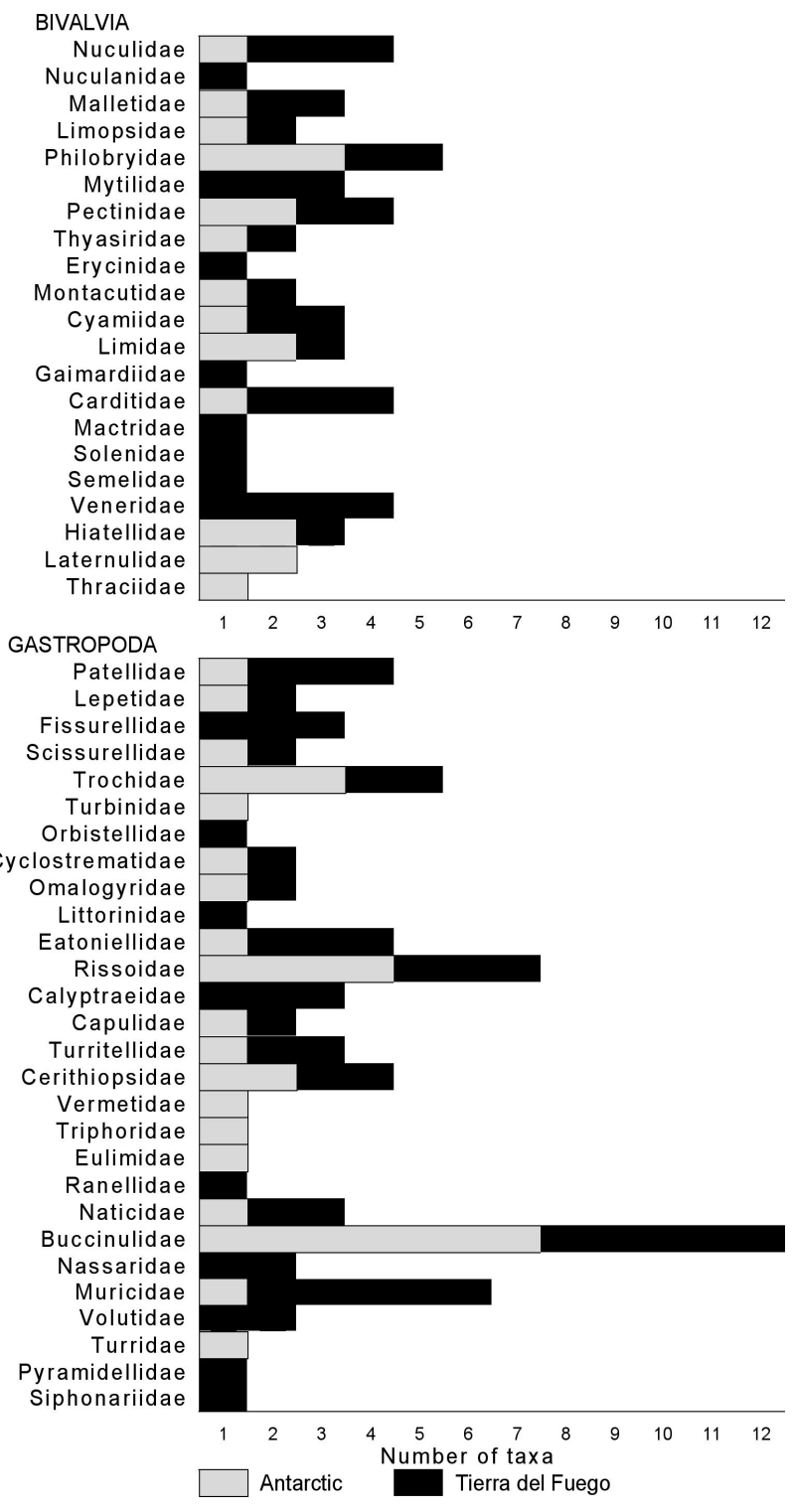

FIG. 3. - Number of gastropods and bivalves per family in the Quaternary of Antarctica and Tierra del Fuego. 
It would appear most likely that most of these affinities and relationships (Fig. 3) are the product of high-latitude radiations in Quaternary times, since they do not reflect ancient similarities (pointed out by Zinsmeister and Feldmann, 1984; and Crame, 1996) during the Palaeogene when the two regions formed part of the Weddellian Province.

\section{SUMMARY AND CONCLUSIONS}

Lindberg and Lipps (1996) refer to the Quaternary period as: "an ideal venue for this cross-training of palaeontologists and neontologists". In this sense cross-disciplinary research that incorporates geological, geomorphological and oceanographic information is also necessary in order to interpret changes in faunal composition during the Quaternary.

In Tierra del Fuego, it is probable that after the glaciers fully receded ( $c a .10 \mathrm{ka} \mathrm{BP})$, the vacant areas were occupied by new communities formed by immigration of species living in any location with geographic access to these new habitats. Our data support the hypothesis that during the interval 5-4 ka BP (under relatively warmer conditions) a major expansion of the fauna took place, and further diversification of mollusc assemblages was characterised by the dominance of Veneridae and the appearance of other families or groups, indicating an evolution towards modern conditions. Most of these species, if not all of them, were able to sustain life in the area, even during Neoglacial climatic deterioration. Local absences of specific groups are best interpreted on the basis of local environmental conditions that create a diversified space, with habitat islands or discontinuities within the continuous seascape. Thus, faunal differences during this period of climatic stability in the marine realm are explained on the basis of different factors which affected these associations: changes in faunal composition following oceanographic episodes after deglaciation; different local environments; and/or episodes of minor climatic fluctuations.

When our data are compared with those from the Antarctic, our evidence supports similarities comprising the oldest ages of Holocene uplifted deposits, climatic conditions and the fact that the oldest postglacial beaches from both regions were developed at about 7-8 ka BP. In both regions, the mollusc group represents the most consistent fossil record, and all the recovered taxa are extant species, with a wide ecological range within their respective surrounding waters. These palaeofaunas overlap only slightly in composition at the species level, but have a considerable number of genera $(23 \%)$ and families $(50 \%)$ in common. These affinities and relationships are best explained on the basis of more recent migrating taxa rather than ancient connections when the two regions formed part of the Weddellian Province.

To conclude, the evidence summarised here shows that, despite major physical changes that produced introductions or exclusions of some elements, the Quaternary mollusc assemblages of Tierra del Fuego and the Antarctic have remained intact during this period. It appears that modern and Quaternary fossil taxa from these regions are "plastic" or broadly tolerant to environmental changes, which allows the fauna to be ecologically and evolutionarily persistent.

\section{ACKNOWLEDGEMENTS}

Geomorphological and palaeoenvironmental studies were carried out thanks to the CONICET grant PIP 4305/96 to Jorge Rabassa. Thanks are extended to the Tierra del Fuego National Park authorities, and to the Goodall family at Estancia Harberton, who kindly provided authorisation to work in their respective domains. Sandra N. Amuchástegui and Daniel R. Aureliano gave their assistance during fieldwork in December 2002. Beatriz Waisfeld (CIPAL) kindly read the manuscript. We are also grateful to Dr. Alistair Crame (BAS) for constructive comments concerning contents and language. Katrin Linse (BAS) shared information regarding living Mollusca. An anonymous reviewer contributed useful suggestions on a previous version of the manuscript.

\section{REFERENCES}

Aguirre, M. - 1990. Asociaciones de moluscos bentónicos marinos del Cuaternario Tardío en el Noreste bonaerense. Ameghiniana, 27: 161-177.

Antezana, T. - 1999a. Hydrographic features of Magellan and Fuegian inland passages and adjacent Subantarctic waters. Sci. Mar., 63(Suppl. 1): 23-34.

Antezana, T. - 1999b. Plankton of southern Chilean fjords: trends and linkages. Sci. Mar., 63(Suppl. 1): 69-80.

Auer, V. - 1959. The Pleistocene of Fuego-Patagonia. Part III: Shoreline displacements. Ann. Acad. Sci. Fenn. A., 3: 45.

Baroni, C. and G. Orombelli. - 1991. Holocene raised beaches at Terra Nova Bay, Victoria Land, Antarctica. Quaternary Res., 36: $157-177$

Berkman, P.A. - 1992. Circumpolar distribution of Holocene marine fossils in Antarctic beaches. Quaternary Res., 37: 256-260. 
Beu, A.G., M. Griffin and P.A. Maxwell. - 1999. Opening of Drake Passage gateway and Late Miocene to Pleistocene cooling reflected in Southern Ocean molluscan dispersal: evidence from New Zealand and Argentina. Tectonophysics, 281: 83-97.

Borromei, A.M. and M. Quattrocchio. - 2001. Palynological study of Holocene marine sediments from Bahía Lapataia, Beagle Channel, Tierra del Fuego. Rev. Esp. Micropaleont., 33 (1): 6170.

Brandt, A., K. Linse and U. Mühlenhardt-Siegel. - 1999. Biogeography of Crustacea and Mollusca of the Subantarctic and Antarctic regions. Sci. Mar., 63(Suppl. 1): 383-389.

Briggs, J.C. - 1995. Developments in paleontology and stratigraphy. Global biogeography, 14. Elsevier. Amsterdam.

Clapperton, C. and D.E. Sugden. - 1982. Late Quaternary glacial history of George VI Sound area, West Antarctica. Quaternary Res., 18: 243-267.

Clapperton, C. and D.E. Sudgen. - 1988. Holocene glacier fluctuations in South America and Antarctica. Quaternary Sci. Rev., 7: 185-198.

Coronato, A., J. Rabassa, A. Borromei, M. Quatroccio and G. Bujalesky. - 1999. Nuevos datos sobre el nivel relativo del mar durante el Holoceno en el Canal Beagle, Tierra del Fuego, Argentina. Actas I Congr. Arg. Cuat. Geomorfol., 27-28.

Crame, J.A. - 1992. Evolutionary history of the polar regions. Historical Biol., 6: 37-60.

Crame, J.A. - 1993. Bipolar molluses and their evolutionary implications. J. Biogeogr., 20: 145-161.

Crame, J.A. - 1996. Evolution of high-latitude molluscan faunas. In: J.D. Taylor (ed.): Origin and evolutionary radiation of the Mollusca, pp. 119-131. Oxford University Press, Oxford.

Crame, J.A.- 1997. An evolutionary framework for the polar regions. J. Biogeogr., 24: 1-9.

Crame, J.A. - 1999. An evolutionary perspective on marine faunal connections between southernmost South America and Antarctica. Sci. Mar., 63(Suppl. 1): 1-14.

Crame, J.A. - 2000. Evolution of taxonomic diversity gradients in the marine realm: evidence from the composition of Recent bivalve faunas. Paleobiology, 26: 188-214.

Dell, R.K. - 1990. Antarctic Mollusca. B. R. Soc. N. Zeal., 27: 1311.

Gordillo S. - 1990. Presencia de Limopsis marionensis Smith, 1885 (Mollusca: Bivalvia) en el Pleistoceno Superior de Tierra del Fuego. Actas XI Congr. Geol. Arg., 2: 219-221. San Juan, Argentina.

Gordillo, S. - 1992. Tafonomía y paleoecología de moluscos del Holoceno del Canal Beagle, Tierra del Fuego. PhD thesis, Univ. Nac. Córdoba.

Gordillo, S. - 1993. Las terrazas marinas holocenas de la región del Beagle (Tierra del Fuego) y su fauna asociada. Actas XII Congr. Geol. Arg., 6: 34-39. Mendoza.

Gordillo, S. - 1999. Holocene molluscan assemblages in the Magellan region. Sci. Mar., 63 (Supl. 1): 15-22.

Gordillo, S., G. Bujalesky, P.A. Pirazzoli, J.O. Rabassa and J.-F. Saliège. - 1992. Holocene raised beaches along the northern coast of the Beagle Channel, Tierra del Fuego, Argentina. Palaeogeogr. Palaeoecl., 99: 41-54.

Gordillo, S., A. Coronato and J.O. Rabassa. - 1993. Late Quaternary evolution of a subantarctic paleofjord, Tierra del Fuego. Quaternary Sci. Rev., 12: 889-897.

Grill, S., A.M. Borromei, M. Quattrocchio, A. Coronato, G Bujalesky and J. Rabassa. - 2002. Palynological and sedimentological analysis of recent sediments from Río Varela, Beagle Channel, Tierra del Fuego, Argentina. Rev. Esp. Micropaleont., 34: $145-161$

Heusser, C.J. - 1989a. Late Quaternary vegetation and climate of southern Tierra del Fuego. Ouaternary. Res., 31: 396-406.

Heusser, C.J. - 1989b. Climate and chronology of Antarctica and adjacent South America over the past 30,000 yr. Palaeogeogr. Palaeocl., 76: 31-37.

Heusser, C. - 1998. Deglacial paleoclimate of the American sector of the Southern Ocean: Late Glacial-Holocene records from the latitude of Canal Beagle $\left(55^{\circ} \mathrm{S}\right)$, Argentine Tierra del Fuego. Palaeogeogr. Palaeocl., 141: 277-301.

Heusser, C. and J.O. Rabassa - 1987. Cold climatic episode of Younger Dryas age in Tierra del Fuego. Nature, 328: 609-611.

Ingólfssson, O., C. Hjort, P.A. Berkman, S. Björck, E. Colhoun, I.D. Goodwin, B. Hall, K. Hirakawa, M. Melles, P. Möller and M.L. Prentice. - 1998. Antarctic glacial history since the Last Glacial
Maximum: an overview of the record on land. Ant. Sci., 10: 326-344.

Ingólfsson, O., C. Hjort and O. Humlum. - 2003. Glacial and climate history of the Antarctic Peninsula since the Last Glacial Maximum. Arct. Anarct. Alp. Res., 35: 175-186.

Isla, F.I. - 1989. Holocene sea-level fluctuations in the Southern Hemisphere. Quaternary. Sci. Rev., 8: 359-368.

Isla, F.I., G. Bujalesky and A. Coronato. - 1999. Procesos estuarinos en el Canal Beagle, Tierra del Fuego. Rev. Asoc. Geol. Arg., 54: 307-318.

Kuylenstierna, J., G. Rosqvist, and P. Holmlund. - 1996. LateHolocene glacier variations in the Cordillera Darwin, Tierra del Fuego, Chile. Holocene 6: 353-358.

Lindberg, D.R. and J.H. Lipps. - 1996. Reading the chronicle of Quaternary temperate rocky shore faunas. In: Jablonski, D., Erwin, D.H. and J.H. Lipps (eds.), Evolutionary Paleobiology, pp. 161-182. The University of Chicago Press, Chicago.

Linse, K. - 1999a. Mollusca of the Magellan region. A checklist of the species and their distribution. Sci. Mar., 63(Suppl. 1): 399-407.

Linse, K. - 1999b. Abundance and diversity of Mollusca in the Beagle Channel. Sci. Mar., 63(Suppl. 1): 391-397.

Linse, K. - 2002. The shelled Magellanic Mollusca: with special reference to biogeographic relations in the Southern Ocean. Theses Zoologicae Vol. 74. A.R.A. Ganter Verlag KG, Ruggell, Liechtenstein, pp. 1-251, 21 plates.

Lubinsky, I. - 1980. Marine bivalve molluscs of the Canadian Central and Eastern Arctic: faunal composition and zoogeography. Can. B. Fish. Aquat. Sci., 207: 1-111.

Moyano, H.I. - 1999. Magellan Bryozoa: a review of the diversity and of the Subantarctic and Antarctic zoogeographical links. Sci. Mar., 63(Suppl. 1): 219-226.

Obelic, B., A. Alvarez, J. Argullós and E.L. Piana. - 1998. Determination of water palaeotemperature in the Beagle Channel (Argentina) during the last $6000 \mathrm{yr}$ through stable isotope composition of Mytilus edulis shells. Quatern. South Amer. Ant. Pen., 11: 47-71.

Orombelli, G., C. Baroni and G.H. Denton. - 1991. Late Cenozoic glacial history of the Terra Nova Bay Region, northern Victoria Land, Antarctica. Geogr. Fis. Dinam. Ouatern., 13: 139-163.

Pickard, J. - 1985. The Holocene fossil marine macrofauna of the Vestfold Hills, East Antarctica. Boreas, 14: 189-202.

Pickard, J., P.M. Selkirk and D.R. Selkirk. - 1983. Holocene climates of the Vestfold Hills, Antarctica, and Macquarie Island. In: Vogel, J.C. (ed.), Late Cainozoic Palaeoclimates of the Southern Hemisphere, pp. 173-182. A.A. Balkema, Rotterdam.

Pickard, J., D.A. Adamson and C.W. Heath. - 1986. The evolution of Watts Lake, Vestfold Hills, East Antarctica, from marine inlet to freshwater lake. Palaeogeogr. Palaeocl., 53: 271-288.

Planas, X., A. Ponsa, A. Coronato and J.O. Rabassa. - 2002. Geomorphological features of Late Glacial-Holocene glaciations in Martial Cirque, Fuegian Andes, southernmost South America. Quatern. Int., 87:19-27.

Ponder, W.F. and T.M. Worsfold. - 1994. A review of the rissoiform gastropods of southwestern South America (Mollusca, Gastropoda). Contr. Sci. Nat. Hist. Mus. L.A. Cty., 445: 1-63.

Rabassa, J., C. Heusser and R. Stuckenrath. - 1986. New data on Holocene sea transgression in the Beagle Channel, Tierra del Fuego, Argentina. Quat. South Amer. Ant. Pen., 4: 291-309.

Rabassa, J., D. Serrat, C. Marti and A. Coronato. - 1990. El Tardiglacial en el Canal Beagle, Tierra del Fuego, Argentina y Chile. Actas XI Congr. Geol. Arg., 1: 290-293. San Juan, Argentina.

Rabassa, J.O., G. Bujalesky, A. Meglioli, A. Coronato, S. Gordillo, C. Roig and M. Salemme. - 1992. The Quaternary of Tierra del Fuego, Argentina: the status of our knowledge. Sve. Geol. Unders., Ser. Ca., 81: 249-256.

Rabassa, J.O., A. Coronato, C. Roig, D. Serrat and O. Martínez. 1996. Geología glacial de Bahía Sloggett, Tierra del Fuego, Argentina. Actas XIII Congr. Geol. Arg., 4: 329. Buenos Aires, Argentina.

Rabassa, J., A. Coronato, G. Bujalesky, C. Roig, M. Salemme, A. Meglioli, C. Heusser, S. Gordillo, A. Borromei and M. Quatrocchio - 2000. Quaternary of Tierra del Fuego, Southernmost South America: an updated review. Quatern. Int., 68-71: 217-240.

Reid, D. and C. Osorio. - 2000. The shallow-water marine Mollusca of the Estero Elefantes and Laguna San Rafael, southern Chile. B. Nat. Hist. Mus. Lond. (Zool.), 66: 109-146. 
Strelin, J., E. Malagnino, T. Sone, G. Casassa, R. Iturraspe, J. Moir and C. Torielli. - 2002. Cronología neoglacial del extremo sur de Sudamérica, Arco de Scotia y Península Antártica. Actas XV Congr. Geol. Arg., 506-511. El Calafate. Argentina.

Taviani, M., A. Beu and C. Lombardo. - 1998. Pleistocene macrofossils from CRP-1 drillhole, Victoria Land Basin, Antarctica. Terr. Antarct., 5: 485-491.

Taviani, M., A. Beu and H.A. Jonkers. - 2000. Macrofossils from CRP-2/2A, Victoria Land Basin, Antarctica. Terr. Antarct., 7: 513-526.

Urien, C. - 1968. Edad de algunas playas elevadas en la Península Ushuaia y su relación con el ascenso costero. III Jorn. Geol. Arg. 2: 35-42.

Vermeij, G.J. - 1978. Biogeography and adaptation: Patterns of marine life. Harvard University Press, Cambridge.

Vermeij, G.J. - 1991. Anatomy of an invasion: the trans-Arctic interchange. Paleobiology, 17: 281-307.

Vermeij, G.J. - 1995. A natural history of shells. Princeton Univer- sity Press

Zinsmeister, W. J. - 1979. Biogeographic significance of the Late Mesozoic and Early Tertiary faunas of Seymour Island (Antarctic Peninsula), pp. 349-355. In: Gray, J. and A. J. Boucot (eds.), Historical biogeography, plate tectonics and changing environment, Oregon State University Press, Corvallis.

Zinsmeister, W.J. - 1984. Late Eocene bivalves (Mollusca) from the La Meseta Formation, collected during the 1974-1975 joint Argentine-American Expedition to Seymour Island, Antarctic Peninsula. J. Paleontol., 58: 1497-1527.

Zinsmeister, W.J. and R.M. Feldmann. - 1984. Cenozoic high latitude heterochronology of Southern Hemisphere marine faunas. Science, 224: 281-283.

Zhang, Q., Y. Xie and Y. Li. - 1983. A preliminary study of the evolution of the Post Late Pleistocene Vestfold Hills environment, East Antarctica. In: Oliver, R.L., P.R. James and J.B. Jago (eds.), Antarctic Earth Science, pp. 473-477. Cambridge University Press. 